\title{
Determination the Quality of BOOTS Shoes at the EIGER STORE Using the Simple Additive Weighting Method
}

\author{
Fredyanto Irawan \\ Universitas Prima Indonesia \\ Information System \\ Medan, Indonesia
}

\author{
M. Diarmansyah Batubara \\ Universitas Prima Indonesia \\ Information System \\ Medan, Indonesia
}

\begin{abstract}
The times change a lot of things, one of them human needs such as shoes. Along with the development of modern life, shoes are an irreplaceable part to maintain one's appearance. So it is very important for companies to provide various types of shoes with certain advantages needed by the community so they can compete with other shoe products. For that reason, the writer tries to make it easier for the seller to make the best shoe recommendations more effectively and efficiently so that they can better utilize the available data to be processed into the recommendations. And the usual manual method is done by looking at the previous shoe data and less considering other criteria with the existence of this support system the results of the recommendations are more accurate and precise. Therefore the researchers made a decision support application using the Simple Additive Weighting (SAW) method, based on web with Dreamweaver Editor application and MySQL database. With the hope that this application will make it easier for the seller to determine the best shoes.
\end{abstract}

Keywords:- Boots Shoes, Decision Support System, SAW, $W E B$

\section{INTRODUCTION}

Today's business world is experiencing rapid change, and increasing technological advances in the modern era that require a company to make a product variant that suits the needs and purchasing power of consumers. as well as shoes. shoes are an irreplaceable part to maintain one's appearance. This is what drives the increasingly rapid business in the field of shoe sales because of the demands of increasingly complex consumer desires, and types of shoes also have advantages and disadvantages of each, depending on the price and material of the shoe itself. So it is very important for companies to provide various types of shoes with certain advantages needed by the community so they can compete with other shoe products. So we need a decision support system that is fast and accurate in recommending the best shoes, in order to provide an explanation to consumers in detail and correctly ${ }^{[1]}$. Decision support system is a system that helps decision makers to use data and various models to solve unstructured problems ${ }^{[2]}$. Another term decision support system is a computer-based / computer-based system that is intended to assist decision making in utilizing certain sata and models ${ }^{[3]}$. The Promethee method is used to determine and produce decisions from several alternatives. In order to obtain solutions or results that can be taken a decision in the form of leaving flow ranking, entering flow, and net flow ${ }^{[4]}$. There are many methods available in the decision support system so it is confused which one is suitable to use the method that is suitable with the case of the decision support system ${ }^{[5]}$. To solve the problem in determining the best shoes, the right course of action is to create a decision support system in determining the best shoes. By utilizing existing data to be used as a comparison in each alternative, so getting the best type of shoes to recommend.

\section{RESEARCH METODOLOGY}

Following are the steps needed to achieve the design goals to be carried out:

\section{Identification of Problems}

At this stage the problem is identified, to identify the problem that occurs at the Eiger Store so that the writer can provide a solution or design that can later facilitate the Eiger Store.

\section{Data Collection}

The author collected data directly to the Eiger Store. Data will be processed to get ranking results.

\section{System Analysis}

The author analyzes the right system in recommending the best Eiger Srtore shoe products, so that later the system designed can help company employees.

\section{System Design}

The author designs the system in accordance with the problems that have been found. This design process translates requirements or needs into software.

\section{System Implementation and Testing}

The program that has been designed will be tested for results. For the validation process will be tested with a blackbox. Decision support system is a computer-based system that produces various alternative decisions to assist management in dealing with various structured or 
unstructured problems using data and models ${ }^{[6]}$. Promethee is a method of determining the order (priority) in multicriteria analysis. The main problem is simplicity, clarity, and stability. The presumption of the predominance of the criteria used in Promethee is the use of values in outranking relationships. This method includes a ranking method which is quite simple in concept and application compared to other methods for multi-criteria analysis ${ }^{[7]}$.

\section{RESULT AND DISCUSSION}

\subsection{Determination of Criteria}

Criteria data are used to make comparisons between alternatives.

$\mathrm{C} 1=$ Design

$\mathrm{C} 2$ = Material

$\mathrm{C} 3=$ Outsole of shoes

$\mathrm{C} 4=$ Midsole shoes

C5 = Price

\begin{tabular}{|c|c|c|c|c|}
\hline Symbol & Name Criteria & W & Sub-criteria & Value \\
\hline $\mathrm{C} 1$ & Design & 0.25 & $\begin{array}{c}\text { Sport } \\
\text { Hiking \& Trekking } \\
\text { Stylis } \\
\text { Casual }\end{array}$ & $\begin{array}{c}1 \\
0.75 \\
0.5 \\
0.25\end{array}$ \\
\hline $\mathrm{C} 2$ & Material & 0.2 & $\begin{array}{c}\text { Leather } \\
\text { Polyster Nubbuck } \\
\text { Nylon } \\
\text { Canvas }\end{array}$ & $\begin{array}{c}1 \\
0.75 \\
0.5 \\
0.25\end{array}$ \\
\hline C3 & Outsole Shoe & 0.35 & $\begin{array}{c}\text { Vibram Rubber Cupsole } \\
\text { Compound Rubber } \\
\text { Xc gripper } \\
\text { Rubber }\end{array}$ & $\begin{array}{c}1 \\
0.75 \\
0.5 \\
0.25\end{array}$ \\
\hline $\mathrm{C} 4$ & Midsole Shoe & 0.12 & $\begin{array}{c}\text { EVA Compress } \\
\text { Phylon } \\
\text { Polyurethane } \\
\text { Plate Shank }\end{array}$ & $\begin{array}{c}1 \\
0.75 \\
0.5 \\
0.25\end{array}$ \\
\hline C5 & Price & 0.08 & $\begin{array}{c}>\text { Rp. } 2.000 .000 \\
\text { Rp.1.000.000 -Rp. } 2.000 .000 \\
\text { Rp.800.000 - Rp. } 1.000 .000 \\
\text { Rp.500.000 - Rp.800.000 }\end{array}$ & $\begin{array}{c}1 \\
0.75 \\
0.5 \\
0.25 \\
\end{array}$ \\
\hline
\end{tabular}

Table 1:- Criteria Data

1.2. Alternatif

\begin{tabular}{|c|c|}
\hline Symbol & Alternative Name \\
\hline A1 & Sepatu Eiger Navajo Mc Boots \\
\hline A2 & Sepatu Eiger Boot Pollock \\
\hline A3 & Sepatu Eiger Mid Boot Shamrock \\
\hline
\end{tabular}

Table 2:- Alternative Data

3.3 Calculation of Preference Values

3.3.1 Determination of Criteria Value of All Alternatives

All alternatives will be assessed based on criteria, as explained in table 3 below.

\begin{tabular}{|c|c|c|c|c|c|}
\hline \multirow{2}{*}{ Alt } & \multicolumn{5}{|c|}{ Criteria } \\
\hline & Design & Material & Outsole & Midsole & Price \\
\hline A1 & Stylis & Polyster & Compound & Phylon & 1.850 .000 \\
\hline $\mathrm{A} 2$ & Hiking Trekking & Nylon & Compound & Phylon & 850.000 \\
\hline A3 & Casual & Leather & XcGripper & Phylon & 950.000 \\
\hline
\end{tabular}

Table 3:- Assessment Criteria of Each Alternative

3.3.2. Determination of the Weight Value of all the criteria of each alternative
After evaluating the criteria for all alternatives, the next step is to transform the value of the criteria into weighting values. 


\begin{tabular}{|c|c|c|c|c|c|}
\hline \multirow{2}{*}{ Alt } & \multicolumn{5}{|c|}{ Criteria } \\
\cline { 2 - 6 } & C1 & C2 & C3 & C4 & C5 \\
\hline A1 & 0.5 & 0.75 & 0.75 & 0.75 & 0.75 \\
A2 & 0.75 & 0.5 & 0.75 & 0.75 & 0.5 \\
A3 & 0.25 & 1 & 0.5 & 0.75 & 0.5 \\
\hline
\end{tabular}

Table 4:- Weight Assessment

3.3.3. Determination of the Maximum Value of each Criteria.

After transforming the value of the criteria into weight values, the next step is to determine the maximum value for each criteria.

\begin{tabular}{|c|c|c|c|c|c|}
\hline \multirow{2}{*}{ Alt } & \multicolumn{5}{|c|}{ Criteria } \\
\cline { 2 - 6 } & C1 & C2 & C3 & C4 & C5 \\
\hline A1 & 0.5 & 0.75 & 0.75 & 0.75 & 0.75 \\
A2 & 0.75 & 0.5 & 0.75 & 0.75 & 0.5 \\
A3 & 0.25 & 1 & 0.5 & 0.75 & 0.5 \\
\hline Max & $\mathbf{0 . 7 5}$ & $\mathbf{1}$ & $\mathbf{0 . 7 5}$ & $\mathbf{0 . 7 5}$ & $\mathbf{0 . 7 5}$ \\
\hline
\end{tabular}

Table 5:- Determination of Maximum Value

\subsubsection{Normalization Calculation Method}

The method of calculating the Normalization of the SAW Method is the value of the criteria weight divided by the maximum value.

\begin{tabular}{|c|c|c|c|c|c|}
\hline \multirow{2}{*}{ Alt } & \multicolumn{5}{|c|}{ Criteria } \\
\cline { 2 - 6 } & $\mathbf{C 1}$ & $\mathbf{C 2}$ & $\mathbf{C 3}$ & $\mathbf{C 4}$ & $\mathbf{C 5}$ \\
\hline $\mathrm{A} 1$ & $0.5 /$ & $0.75 /$ & $0.75 /$ & $0.75 /$ & $0.75 /$ \\
$\mathrm{A} 2$ & $\mathbf{0 . 7 5}$ & $\mathbf{1}$ & $\mathbf{0 . 7 5}$ & $\mathbf{0 . 7 5}$ & $\mathbf{0 . 7 5}$ \\
$\mathrm{A} 3$ & $0.75 /$ & $0.5 /$ & $0.75 /$ & $0.75 /$ & $0.5 /$ \\
& $\mathbf{0 . 7 5}$ & $\mathbf{1}$ & $\mathbf{0 . 7 5}$ & $\mathbf{0 . 7 5}$ & $\mathbf{0 . 7 5}$ \\
& $0.25 /$ & $1 / \mathbf{1}$ & $0.5 / \mathbf{0 . 7 5}$ & $0.75 /$ & $0.5 /$ \\
& $\mathbf{0 . 7 5}$ & & & $\mathbf{0 . 7 5}$ & $\mathbf{0 . 7 5}$ \\
\hline
\end{tabular}

Table 6:- Normalization Calculation

After dividing the criteria weights from the maximum value, the Normalization value will be generated.

\begin{tabular}{|c|c|c|c|c|c|}
\hline \multirow{2}{*}{ Alt } & \multicolumn{5}{|c|}{ Criteria } \\
\cline { 2 - 6 } & C1 & C2 & C3 & C4 & C5 \\
\hline A1 & 0.667 & 0.75 & 1 & 1 & 1 \\
A2 & 1 & 0.5 & 1 & 1 & 0.667 \\
A3 & 0.333 & 1 & 0.667 & 1 & 0.667 \\
\hline
\end{tabular}

Table 7:- Normalization Results

3.3.5. Determination of the Vi value from the Simple Additive Weighted method.

To get the value of $\mathrm{Vi}$ is to do a matrix multiplication between the results of normalization and the importance of weight.

$\mathrm{Vi}=\left(\begin{array}{ccccc}0.667 & 0.75 & 1 & 1 & 1 \\ 1 & 0.5 & 1 & 1 & 0.667 \\ 0.333 & 1 & 0.667 & 1 & 0.667\end{array}\right\} \quad X \quad\left\{\begin{array}{l}0.250 \\ 0.200 \\ 0.350 \\ 0.120 \\ 0.080\end{array}\right\}$
Then the preference value of each alternative.

$\mathrm{V} 1$ for $\mathrm{A} 1=(0.667 \times 0.20)+(0.75 \times 0.20)+(1 \times 0.20)+$ (1x0.20)

$$
+(1 \times 0.020) \text {. }
$$

$\mathrm{V} 2$ for $\mathrm{A} 2=(1 \times 0.20)+(0.5 \times 0.20)+(1 \times 0.20)+(1 \times 0.20)$

$$
+(0.667 \times 0.20) \text {. }
$$

$\mathrm{V} 3$ for $\mathrm{A} 3=(0.333 \times 0.20)+(1 \times 0.20)+(0.667 \times 0.20)$

$$
+(1 \times 0.20)+(0.667 \times 0.020)
$$

\subsubsection{Results.}

After calculating the value of $\mathrm{Vi}$, the following values can be obtained:

$\mathrm{V} 1$ for $\mathrm{A} 1=0.8667$

$\mathrm{V} 2$ for $\mathrm{A} 2=0.8733$

$\mathrm{V} 3$ for $\mathrm{A} 3=0.69$

\subsection{Ranking}

Based on calculations performed using the Simple Additive Weighting method, the results shown in table 3. have been selected for the best shoe product as alternative B (Eiger Boot Pollock Shoes) with a 0.873 SAW Value.

\begin{tabular}{|c|c|c|}
\hline Code & Alternatif & SAW Value \\
\hline A2 & Eiger Boot Pollock & 0.873 \\
\hline A1 & Eiger Navajo Mc Boots & 0.867 \\
\hline A3 & $\begin{array}{c}\text { Eiger Mid Boot } \\
\text { Shamrock }\end{array}$ & 0.69 \\
\hline
\end{tabular}

Table 8:- Ranking

\section{CONCLUSION AND SUGGEST}

\section{Conclusion:}

1. In recommending the best shoe products the Simple Additive Weighting method is applied in a calculation, where the results from the highest ranking are the best shoe choices.

2. To produce good shoe recommendations, a combination of the Simple Additive Weighting method and the application system has been designed, so that the shoe determination process is more effective and efficient so that the level of accuracy reaches $100 \%$.

3 . The results of shoe data management are presented in the form of a report, where the report is obtained based on the results of ranking by the method of Simple Additive Weighting. With this report, it is easier for the head of the store to see the results of good recommendations.

\section{Suggest:}

1. More developed about the appearance of the Promethee calculation, so it is easier to understand.

2. The need to add features so that the system is not only used as a determination system but can be used for other things.

3. For further development the system can be changed to be based online not only in desktop form. 


\section{REFERENCES}

[1]. Hutapea, B, J., Hasmi, M. A., Karim, A., \& Suginam, S. (2018), Sistem Pendukung Keputusan Penentuan Jenis Kulit Terbaik Untuk Pembuatan Sepatu Dengan Menggunakan Metode VIKTOR. JURIKOM (Jurnal Riset Komputer), 5(1), 6-12

[2]. Tanti, L. (2016). Penerapan Metode Promethee Dalam Evaluasi Kualitas Layanan Unit Kerja. semnasteknomedia online, 4(1), 1-3.

[3]. Saleh, A. (2017). Penerapan Metode Simple Multi Attribute Rating Technique Exploiting Rank Dalam Sistem Pendukung Keputusan Rekrutmen Asisten Laboratorium Komputer. Masyarakat Telematika dan Informasi, 8(1), 1-10

[4]. Safrizal, S., \& Tanti, L. (2015). Penerapan Metode Promethee Dalam Penyeleksian Siswa Baru (Airlines Staff) pada LPP Penerbangan. Proceedings Konferensi Nasional Sistem dan Informatika (KNS\&I).

[5]. Meizar,A. (2018). Implementasi Analityc Hierarchy Process Dan Simple Additive WeightedDalam Pemilihan Karyawan Berprestasi. Jurnal Sistem Informasi Keputama (JSIK) Vol 2 no.1

[6]. Priyanto, F. S., Harijanto, B., \& Watequlis, Y. (2017). Sistem Pendukung Keputusan Pemilihan Guru Berprestasi Menggunakan Metode Promethee (Studi Kasus: Dinas Pendidikan Kota Malang). Jurnal Informatika Polinema, 3(4), 23-23.

[7]. Priyanto, F. S., Harijanto, B., \& Watequlis, Y. (2017). Sistem Pendukung Keputusan Pemilihan Guru Berprestasi Menggunakan Metode Promethee (Studi Kasus: Dinas Pendidikan Kota Malang). Jurnal Informatika Polinema, 3(4), 23-23.

[8]. Sari,R.E., Harahap, A. Y. N., \& Meizar, A.(2018, August). Analizing Topsis Method forSelection the Best Wood Type. $20186^{\text {th }}$ International Conference on Cyber and IT Service Management (CITSM) (pp.16).IEEE

[9]. Meizar, A. (2018). SISTEM PENDUKUNG KEPUTUSAN CALON PEMILIHAN DPRD PARTAI AMANAT NASIONAL DARI CABANG LUBUK PAKAM. Jurnal Sistem Informasi dan Ilmu Komputer Prima (JUSIKOM PRIMA), 2(1).

[10]. Sihombing, Oloan, Giovani Ruth Hanoso, Yonata Laia, Halim Maulana, Saut Parsaoran Tamba, Marlince NK Nababan, Evta Indra, M. Diarmansyah Batubara, and Niskarto Zendrato. "Determining Outstanding Employee Using Simple Multi-Attribute Rating Technique Method." In Journal of Physics: Conference Series, vol. 1230, no. 1, p. 012076. IOP Publishing, 2019.

[11]. Sihombing, Oloan, Giovani Ruth Hanoso, Yonata Laia, Halim Maulana, Saut Parsaoran Tamba, Marlince NK Nababan, Evta Indra, M. Diarmansyah Batubara, and Niskarto Zendrato. "Determining Outstanding Employee Using Simple Multi-Attribute Rating Technique Method." In Journal of Physics: Conference Series, vol. 1230, no. 1, p. 012076. IOP Publishing, 2019. 